\title{
PENGARUH MODEL PEMBELAJARAN NHT INTEGRATED TERHADAP KEMAMPUAN BERPIKIR KREATIF DENGAN MENGONTROL KEMAMPUAN AWAL SISWA
}

\author{
Nice Anggraini ${ }^{1}$, Syamsurizal $^{2}$, Jefri Marzal ${ }^{3}$ \\ ${ }^{1,2,3}$ Magister Pendidikan Matematika, Universitas Jambi \\ E-mail: nice.anggraini@yahoo.com ${ }^{l)}$
}

Received 20 October 2018; Received in revised form 10 December 2018; Accepted 26 December 2018

\begin{abstract}
This study aims to see the effect of the NHT Integrated learning model on the ability to think creatively by controlling students' initial abilities. The method used is an experiment with anacova quantitative approach. The population is all students of class VII MTS. The sampling technique used by simple random sampling with 3 classes of samples. In the experimental class using the NHT integrated learning model and the control class using conventional NHT learning models. Data were collected using written test techniques, data analysis techniques in hypothesis testing using ancova with $3 x 1$ factorial and continued with further testing. Based on the results of the study it can be concluded that (1) There is an influence of the NHT integrated learning model on the ability to think creatively by controlling the early ability of mathematics. Given the value of $F_{\text {count }}=8.696>F_{\text {table }} 3.15$ and significance of SPSS 0.000 compared to the value of $\alpha(0.05)$ then $0.000<0.05$ and the hypothesis is accepted. (2) There is a different effect of NHT integrated learning model on the ability to think creatively by controlling the initial ability of mathematics. With the value of $F_{\text {count }}=49.192>F_{\text {table }} 3.15$ and the significance of SPSS 0.000 when compared with the value of $\alpha(0.05)$ then $0.000<0.05$ and the hypothesis is accepted. This difference is seen in the significance level of SPSS $0.001<0.05$, which means that the NHT integrated learning model learning model is better than convensional NHT learning models.
\end{abstract}

Keywords: Creative Thinking Ability; Initial Ability; Integrated NHT

\section{PENDAHULUAN}

Pendidikan adalah setiap usaha, pengaruh, perlindungan dan bantuan yang diberikan kepada anak tertuju kepada pendewasaan anak atau lebih tepat membantu anak agar cukup cakap dalam melaksanakan tugas hidupnya sendiri. Meningkatkan mutu pendidikan menuntut kerja keras berbagai pihak. Mulai dari tenaga pendidik, orang tua, peserta didik, masyarakat dan pemerintah untuk mencapai tujuan akhir yaitu sumber daya manusia yang berkualitas sehingga peserta didik perlu disiapkan sejak dini. Menurut Syah (Faturrahman, Ahmadi, Amri \& Setyono. 2012) "Dalam pengertian yang agak luas pendidikan diartikan sebagai sebuah proses dengan metode-metode tertentu sehingga orang memperoleh pengetahuan, pemahaman dan cara tingkahlaku yang sesuai dengan kebutuhan".

Salah satu bagian tingkatan kemampuan matematika yang terjadi dalam pembelajaran matematika adalah kemampuan berpikir kreatif. Menurut Anwar, Rasool \& Haq (2012), berfikir kreatif adalah cara baru dalam melihat dan mengerjakan sesuatu yang memuat 4 aspek antara lain, fluency (kefasihan), flexybility (keluwesan), originality (keaslian), dan elaboration (keterincian). Sedangkan menurut Ali \& Asrori (2009:42), kreativitas merupakan kemampuan seseorang untuk menciptakan sesuatu yang sama sekali baru atau kombinasi dari karya-karya yang telah ada sebelumnya menjadi suatu karya baru yang dilakukan melalui interaksi dengan lingkungannya untuk menghadapi permasalahan dan

\section{$390 \mid$ AKSIOMA}

Jurnal Pendidikan Matematika FKIP Univ. Muhammadiyah Metro 
mencari alternatif pemecahannya melalui cara-cara berpikir divergen.

Adapun indikator yang terdapat pada kemampuan berpikir kreatif menurut Munandar (Hendriana \& Soemarmo, 2017) menyatakan ada empat indikator: pertama fluency yaitu mencetuskan banyak ide, banyak jawaban, banyak penyelesaian masalah, banyak pertanyaan dengan lancar, memberi banyak cara atau saran untuk melakukan berbagai hal, selalu memikirkan lebih dari satu jawaban, menyelesaiakan masalah dengan cara yang telah ditetapkan. Kedua flexibility yaitu menghasilkan gagasan, jawaban, atau pertanyaan yang bervariasi, dapat melihat suatu masalah dari sudut pandang yang berbeda-beda, memberikan banyak alternatif jawaban, mampu mengubah cara pendekatan atau cara pemikiran. Ketiga originality yaitu mampu melahirkan ungkapan yang baru, memikirkan cara yang tidak lazim untuk mengungkapkan diri, mampu membuat kombinasi-kombinasi yang tidak lazim dari bagian-bagian atau unsur-unsur. Keempat elaboration yaitu mampu memperkaya dan mengembangkan suatu gagasan atau produk, merinci detail-detail dari suatu objek, gagasan, atau permasalahan.

Sedangkan menurut Rudyanto (2016) indikator kemampuan berpikir kreatif dibedakan menjadi (1) fluency meliputi menghasilkan banyak gagasan/jawaban. (2) elaboration meliputi kemampuan memuliki gagasan yang luas, kemampuan merinci detaildetail tertentu. (3) flexibility meliputi mampu menghasilkan gagasan, jawaban atau pertanyaan dari sudut pandang yang berbeda-beda, kemampuan memberikan arah pemikiran yang berbeda. (4) originality meliputi banyaknya variasi memberikan jawaban yang tidak lazim, lain dari yang lain yang jarang diberikan, banyak variasi kemampuan memberikan arah yang berbeda.

Berdasarkan hasil observasi yang dilakukan pada kelas VII MTS, dalam kenyataannya masih terdapat beberapa masalah yang terjadi di dalam proses pembelajaran, seperti kurangnya kemampuan berpikir kreatif siswa. Indikator yang diharapkan dalam kemampuan berpikir kreatif masih banyak yang belum dikuasai oleh siswa, sehingga terdapat siswa yang belum mampu menyampaikan ide-ide mereka serta bagaimana cara penyelesaian masalah dalam menyelesaikan soal. Siswa cenderung mencontoh penyelesaian soal dari apa yang dijelaskan guru saja. Jika siswa diberikan soal yang berbeda dari contoh yang dijelaskan, maka siswa mengalami kebingungan dan kesulitan dalam menyelesaikannya. Dalam menyelesaikan soal, siswa juga cenderung merasa penyelesesaian soal yang dikerjakannya sudah cukup, sehingga tidak ada penambahan penyelesaian soal lain yang diharapkan muncul dari kreatifitas mereka. Hal ini berdampak bagi siswa itu sendiri, jika siswa yang belum mampu mengembangkan kemampuan berpikir kreatif matematikanya, maka akan berpengaruh terhadap hasil belajar. Karena dengan berpikir kreatif siswa akan mampu mengembangkan ide-ide, gagasan, serta hal-hal baru yang mampu mengubah cara pandang, cara berpikir dan pendekatan mereka.

Berdasarkan masalah tersebut, sebenarnya penyampaian proses pembelajaran yang dilakukan oleh guru sudahlah baik. Hanya saja guru kurang memperhatikan aktifitas belajar yang terjadi pada kelas VII MTS yang mengarah kepada kemampuan berpikir kreatif, karena proses pembelajaran cenderung pada penekanan materi saja. Maka guru selaku pendidik diharapkan 
mampu memilih dan menggunakan model pembelajaran yang tepat, agar konsep yang disampaikan dan dijelaskan dapat diterima dan dipahami dengan baik oleh siswa. Guru tidak harus terpaku dalam menggunakan berbagai variasi strategi atau metode, tetapi bagaimana memikat perhatian siswa untuk ikut terlibat aktif dan mampu mengembangkan potensi kreatifitas berpikir siswa dengan baik.

Berdasarkan masalah tersebut, maka perlu adanya model pembelajaran yang dapat mengatasi permasalahan kemampuan berpikir kreatif, seperti model pembelajaran kooperatif. Salah satu ciri model pembelajaran kooperatifnya adalah kerja kelompok yang dibentuk berdasarkan kemampuan secara heterogen, sebagian besar aktifitas pembelajaran yang berpusat pada siswa. Berdasarkan ciri-ciri model pembelajaran tersebut, adapun solusi yang akan dilakukan peneliti dalam meningkatkan kemampuan berpikir kreatif dalam proses pembelajaran adalah dengan menerapkan model pembelajaran kooperatif NHT (Numbered Head Together).

Menurut Prayoga

"model kooperatif tipe NHT merupakan salah satu tipe pembelajaran kooperatif yang menekankan pada struktur khusus yang dirancang untuk mempengaruhi pola interaksi siswa dan memiliki tujuan untuk meningkatkan penguasaan akademik". Seperti kesimpulan penelitian yang dilakukan oleh Sulistyana (2017) tentang pengaruh model pembelajaran kooperatif tipe NHT (Numbered Head Together) terhadap berpikir kreatif yang menyatakan bahwa dengan diterapkannya model pembelajaran NHT (Numbered Head Together) dapat membuat kriteria berpikir kreatif siswa kelas eksperimen baik dibandingkan kelas kontrol yang hanya cukup. Hasil penelitian menunjukkan terdapat hasil yang signifikan model pembelajaran kooperatif tipe NHT (Numbered Head Together) terhadap berpikir kreatif.

Model pembelajaran NHT yang diterapkan dalam penelitian ini adalah model pembelajaran NHT integrated. Integrated artinya terpadu, yaitu memadukan atau disatukan. Dalam hal ini adalah memadukan antara model pembelajaran NHT dan STAD, serta pendekatan saintifik dalam proses pembelajaran. Kegiatan pembelajaran yang demikian dapat mengembangkan kompetensi siswa, sehingga pada prosesnya melalui model pembelajaran NHT integrated yang diberikan diharapkan mampu mengembangkan kemampuan berfikir kreatif.

Namun agar proses pembelajaran lebih efektif, perlu adanya pengetahuan dari guru tentang kemampuan awal siswa. Kemampuan awal siswa merupakan serangkaian pengetahuan yang sebelumnya telah dimiliki oleh siswa. Kemampuan awal yang dimiliki siswa sudah pasti berbeda-beda, baik itu kemampuan awal tinggi, sedang dan rendah. Dengan kemampuan awal siswa yang berbeda-beda tersebut tentunya berdampak pada hasil belajar yang dimiliki siswa pun juga akan berbedabeda. Hal tersebut dikarenakan bagaimana siswa menghubungkan pemahaman yang mereka dapatkan berdasarkan pengetahuan yang mereka miliki sebelumnya.

Dengan demikian agar pengaruh model pembelajaran yang di terapkan dalam penelitian ini dapat terlihat, maka kemampuan awal matematika siswa akan di kontrol secara statistik. Keterlibatan kemampuan awal dalam model pembelajaran juga dapat membantu dalam pembentukan kelompok, karena dengan menetapkan kelompok belajar secara heterogen berdasarkan kemampuan siswa, 
diharapkan dapat membantu meningkatkan kemampuan berpikir kreatif siswa yang berkemampuan awal rendah dan sedang serta dapat meningkatkan kebermaknaan pengajaran.

Tujuan dari penelitian ini adalah (1) Untuk mengetahui pengaruh model pembelajaran NHT integrated terhadap kemampuan berpikir kreatif dengan mengontrol kemampuan awal matematika siswa (2) Untuk mengetahui pengaruh perbedaan model pembelajaran NHT integrated terhadap kemampuan berpikir kreatif dengan mengontrol kemampuan awal matematika siswa.

\section{METODE PENELITIAN}

Adapun jenis penelitian yang digunakan merupakan pendekatan kuantitatif dengan metode eksperimen pendekatan Anacova (Analisys of Covariats). Ancova adalah penggabungan antara uji komparatif dan korelasional, dalam hal ini akan menguji perbandingan sekaligus hubungan. Istilah kova dalam anakova berasal dari kata kovarian (covariance) yang menunjukkan adanya variabel yang dihubungkan yaitu antara variabel bebas kovariat dengan variabel terikat (Supardi, 2014:397).

Variabel pada penelitian ini terdiri dari (1) variabel bebas yaitu model pembelajaran NHT Integrated, (2) variabel terikat yaitu kemampuan berpikir kreatif dan (3) variabel moderator yaitu kemampuan awal yang dikontrol secara statistik.

Adapun rancangan penelitian menggunakan Quasi-Eksperiment Design dengan jenis pretest and posttest design. Adapun desain penelitiannya menurut (Creswell, 2008:314) pada Tabel 1.

Tabel 1. Desain Quasy Eksperiment (Pre and Posttest Design)

\begin{tabular}{cccc}
\hline Kelompok & Pre-test & Perlakuan & Post-test \\
\hline Eksperimen 1 & $\mathrm{Y}_{1}$ & $\mathrm{X}_{1}$ & $\mathrm{Y}_{2}$ \\
Eksperimen 2 & $\mathrm{Y}_{1}$ & $\mathrm{X}_{2}$ & $\mathrm{Y}_{2}$ \\
Kontrol & $\mathrm{Y}_{1}$ & - & $\mathrm{Y}_{2}$
\end{tabular}

Keterangan: $\quad \mathrm{Y}_{2}=$ Tes akhir yang diberikan kepada $\mathrm{X}_{1}$ dan $\mathrm{X}_{2}=$ Perlakuan yang diberikan kelas eksperimen dan kelas kontol pada kelas eksperimen 1 Rancangan penelitian dan kelas eksperimen 2 menggunakan faktorial $3 \quad x \quad 1$ dapat $\mathrm{Y}_{1}=$ Tes kemampuan awal yang dilihat pada tabel rancangan penelitian diberikan pada kelas eksperimen ancova (Supardi, 2014:399) pada Tabel dan kelas kontrol 2.

Tabel 2. Rancangan Penelitian Ancova

$\frac{\mathrm{A}_{1}}{\left(\mathrm{X}_{1} \mathrm{Y}_{1}\right)}$
kelas eksperimen
kelas eksperimen

Keterangan:

A = Variabel perlakuan/treatment

$\mathrm{A}_{1}=$ Perlakuan pada kelas eksperimen 1

$\mathrm{A}_{2}=$ Perlakuan pada kelas eksperimen 2 
Hasil rancangan penelitian dapat disajikan dalam bentuk matriks pada

Tabel 3. Matriks Ancova

\begin{tabular}{cccccc}
\hline & $\mathrm{A}_{1}$ & \multicolumn{3}{c}{$\mathrm{A}_{2}$} & \multicolumn{2}{c}{$\mathrm{A}_{3}$} \\
\hline $\mathrm{O}_{1}$ & $\mathrm{O}_{4}$ & $\mathrm{O}_{2}$ & $\mathrm{O}_{5}$ & $\mathrm{O}_{3}$ & $\mathrm{O}_{6}$ \\
\hline $\mathrm{X}_{11}$ & $\mathrm{Y}_{11}$ & $\mathrm{X}_{21}$ & $\mathrm{Y}_{21}$ & $\mathrm{X}_{31}$ & $\mathrm{Y}_{31}$ \\
$\mathrm{X}_{12}$ & $\mathrm{Y}_{12}$ & $\mathrm{X}_{22}$ & $\mathrm{Y}_{22}$ & $\mathrm{X}_{32}$ & $\mathrm{Y}_{32}$ \\
$\mathrm{X}_{13}$ & $\mathrm{Y}_{13}$ & $\mathrm{X}_{23}$ & $\mathrm{Y}_{23}$ & $\mathrm{X}_{33}$ & $\mathrm{Y}_{33}$ \\
$\ldots$ & $\ldots$ & $\ldots$ & $\ldots$ & $\ldots$ & $\ldots$ \\
$\mathrm{X}_{1 \mathrm{nl}}$ & $\mathrm{Y}_{1 \mathrm{nl}}$ & $\mathrm{X}_{2 \mathrm{nl}}$ & $\mathrm{Y}_{2 \mathrm{nl}}$ & $\mathrm{X}_{3 \mathrm{nl}}$ & $\mathrm{Y}_{3 \mathrm{nl}}$ \\
\hline
\end{tabular}

Keterangan:

$\mathrm{O}_{1}, \mathrm{O}_{2}$ dan $\mathrm{O}_{3}=$ variabel kovariat kemampuan awal

$\mathrm{A}_{1}, \mathrm{~A}_{2}$ dan $\mathrm{A}_{3}=$ Perlakuan pada kelas eksperimen dan kelas kontrol

Populasi di ambil dari seluruh siswa Kelas VII MTS JAUHARUL FALAH Sungai Terap, yang dilakukan dengan cara simple random sampling dengan terlebih dahulu melakukan uji persyaratan analisis seperti uji normalitas dan homogenitas sampel, kemudian didapatkan tiga kelas sampel yaitu dua kelas eksperimen dan satu kelas kontrol. Adapun jumlah siswa pada kelas eksperimen 1 yaitu 19 siswa, pada kelas eksperimen 2 yaitu 21 siswa dan pada kelas kontrol yaitu 23 siswa.

Teknik pengumpulan data dalam penelitian adalah tes tertulis. Instrumen penelitian digunakan untuk mendapatkan data penelitian adalah soal tes berbentuk uraian atau essay. Berfungsi untuk mengukur kemampuan awal matematika siswa dan kemapuan berpikir kreatif siswa terhadap model pembelajaran yang digunakan. Agar soal yang disusun memiliki kriteria sebagai soal yang baik, maka soal-soal tersebut perlu di uji cobakan terlebih dahulu kemudian dianalisis dengan melakukan uji validitas, daya beda,
Tabel 3 matriks ancova. kreatif kemampuan berpikir

indeks kesukaran dan reabilitas. Soal yang telah disusun kemudian di uji cobakan di luar sampel penelitian.

Untuk mendapatkan kesimpulan dari hasil penelitian, maka perlu analisis data terhadap data yang diperoleh. Analisis data merupakan kegiatan yang dilakukan setelah data terkumpul. Oleh sebab itu untuk melakukan uji analisis terlebih dahulu melakukan uji persyaratan analisis yaitu dengan melakukan uji normalitas, homogenitas dan uji linieritas. Setelah uji persayaratan analisis dilakukan, maka akan dilakukan pengujian hipotesis dengan menggunakan ancova (Analisys of Covariats). Kemudian akan dilakukan uji lanjut untuk melihat perbedaan antara model pembelajaran NHT Integrated terhadap kemampuan berpikir kreatif dengan mengontrol kemampuan awal.

\section{HASIL PENELITIAN DAN PEMBAHASAN}

Data hasil tes kemampuan berpikir kreatif diperoleh dari tes akhir

\section{4 | AKSIOMA}

Jurnal Pendidikan Matematika FKIP Univ. Muhammadiyah Metro 
ISSN 2089-8703 (Print) Vol. 7, No. 3 (2018) 390-402

ISSN 2442-5419 (Online)

yang dilakukan pada kelas eksperimen 1 dengan model pembelajaran kooperatif tipe NHT Interated, eksperimen 2 dengan model pembelajaran kooperatif tipe NHT Integrated dan kelas kontrol dengan model pembelajaran kooperatif tipe NHT konvensional. Tes ini dilakukan sesudah model pembelajaran diterapkan, yang bertujuan untuk melihat peningkatan kemampuan berpikir kreatif berdasarkan kemampuan awal yang dimiliki oleh siswa. Pada hasil tes kemampuan awal didapat deskripsi data pada Tabel 4 berikut.

Tabel 4. Deskripsi Data Tes Kemampuan Awal

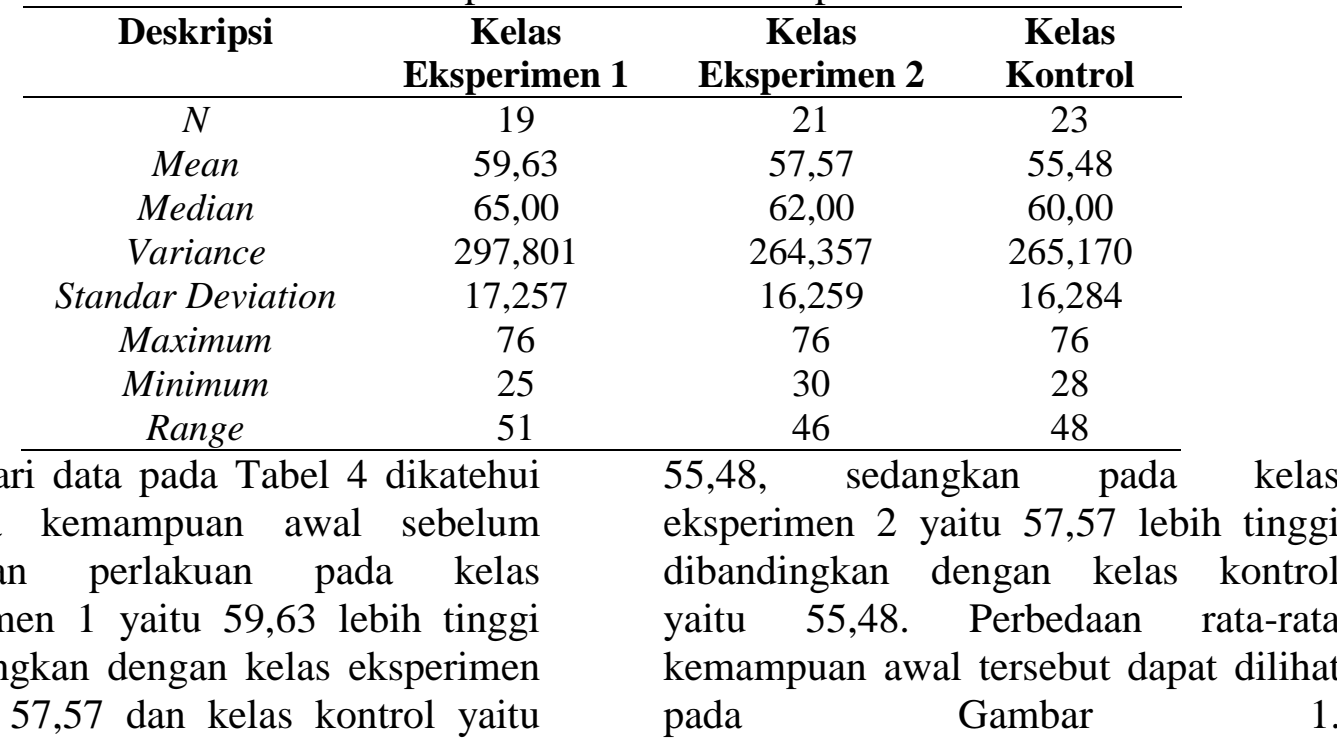

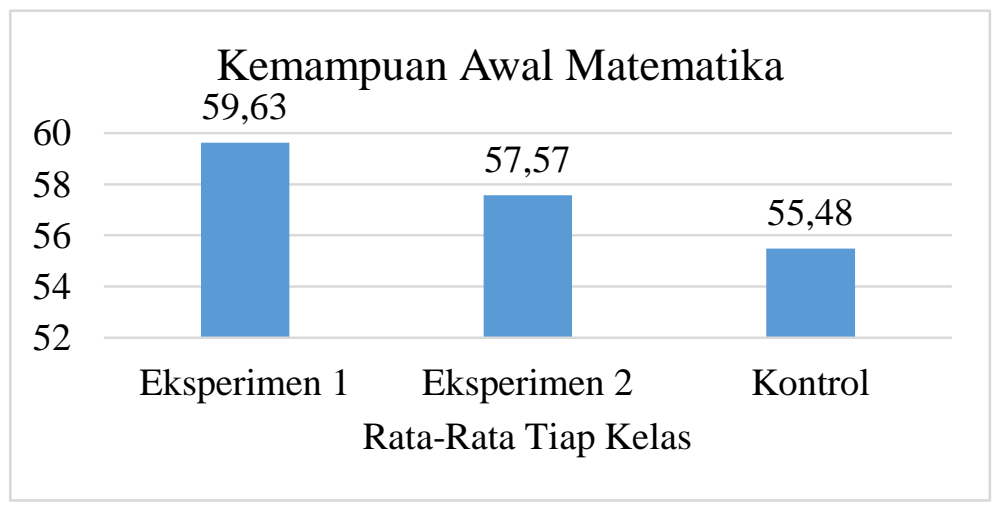

Gambar 1. Rata-Rata Kemampuan Awal

Pada hasil tes kemampuan berpikir

kreatif didapat deskripsi data pada

Tabel 5 berikut.

Tabel 5. Deskripsi Data Tes Kemampuan Berpikir Kreatif

\begin{tabular}{cccc}
\hline Deskripsi & $\begin{array}{c}\text { Kelas } \\
\text { Eksperimen 1 }\end{array}$ & $\begin{array}{c}\text { Kelas } \\
\text { Eksperimen 2 }\end{array}$ & $\begin{array}{c}\text { Kelas } \\
\text { Kontrol }\end{array}$ \\
\hline$N$ & 19 & 21 & 23 \\
Mean & 69,95 & 68,61 & 60,78 \\
Median & 73,00 & 68,00 & 63,00 \\
\hline
\end{tabular}


ISSN 2089-8703 (Print) Vol. 7, No. 3 (2018) 390-402

ISSN 2442-5419 (Online)

\begin{tabular}{cccc}
\hline Variance & 102,386 & 99,748 & 142,269 \\
Standar Deviation & 10,119 & 9,987 & 11,928 \\
Maximum & 85 & 85 & 80 \\
Minimum & 50 & 52 & 43 \\
\hline
\end{tabular}

Dari data pada tabel 5 diketahui pada kelas eksperimen 2 yaitu 68,61 bahwa rata-rata perbedaan hasil belajar lebih tinggi dibandingkan dengan kelas setelah dilakukan perlakuan pada kelas kontrol yaitu 60,78. Perbedaan rata-rata eksperimen 1 yaitu 69,95 lebih tinggi kemampuan berpikir kreatif tersebut dari kelas eksperimen 2 yaitu 68,61 dan dapat dilihat pada Gambar 2. kelas kontrol yaitu 60,78. Sedangkan

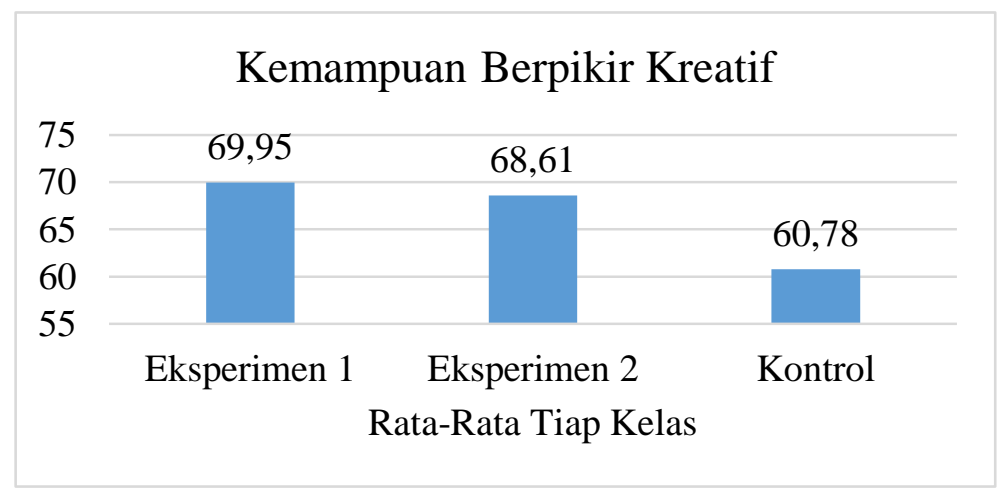

Gambar 2 Rata-Rata Kemampuan Berpikir Kreatif

Untuk dapat mengambil kesimpulan dari hasil penelitian maka dilakukan analisis terhadap data hasil tes akhir. Untuk dapat menganalisis data terlebih dahulu dilakukan uji normalitas, homogenitas terhadap tiga kelas sampel dan uji linieritas terhadap kemampuan awal matematika (kovariat) dengan kemampuan berpikir kreatif.
Adapun hasil uji normalitas data yang dilakukan pada hasil tes kemampuan awal matematika dan hasil tes kemampuan berpikir kreatif, dengan menggunakan uji kolmogorov-smirnov dengan bantuan IBM SPSS Statistik 21.

Berikut hasil pengujian normalitas pada kemampuan awal matematika pada Tabel 6.

Tabel 6. Hasil Uji Normalitas Kemampuan Awal

\begin{tabular}{llcccc}
\hline No & \multicolumn{1}{c}{ Kelas } & N & Sig & $\boldsymbol{\alpha}$ & Sig $>\boldsymbol{\alpha}$ \\
\hline $\mathbf{1}$ & Eksperimen 1 & 19 & 0,082 & 0,05 & Normal \\
$\mathbf{2}$ & Eksperimen 2 & 21 & 0,078 & & \\
$\mathbf{3}$ & Kontrol & 23 & 0,200 & & \\
\hline
\end{tabular}

Berdasarkan Tabel 6 diketahui kemampuan awal matematika memiliki masing-masaing kelas sampel memiliki nilai signifikansi lebih dari $\alpha(0,05)$, sehingga dapat disimpulkan bahwa semua kelas sampel pada uji data berdistribusi normal.

Berikut hasil pengujian normalitas pada kemampuan berpikir kreatif pada Tabel 7.

Tabel 7. Hasil Uji Normalitas Kemampuan Berpikir Kreatif

\begin{tabular}{lccccc}
\hline No & Kelas & N & Sig & $\boldsymbol{\alpha}$ & Sig $>\boldsymbol{\alpha}$ \\
\hline $\mathbf{1}$ & Eksperimen 1 & 19 & 0,200 & 0,05 & Normal \\
$\mathbf{2}$ & Eksperimen 2 & 21 & & & \\
\hline
\end{tabular}

\section{$396 \mid$ AKSIOMA}

Jurnal Pendidikan Matematika FKIP Univ. Muhammadiyah Metro 


\begin{tabular}{lll}
\hline 3 & Kontrol & 23 \\
\hline
\end{tabular}

Berdasarkan Tabel 7 diketahui masing-masaing kelas sampel memiliki nilai signifikansi lebih dari $\alpha(0,05)$, sehingga dapat disimpulkan bahwa semua kelas sampel pada uji kemampuan berprikir kreatif memiliki data berdistribusi normal.

Adapun hasil uji normalitas data yang dilakukan pada hasil tes Tabel 8. Hasil Uji Homogenitas Kemampuan Awal

\begin{tabular}{llcccc}
\hline No & \multicolumn{1}{c}{ Kelas } & N & Sig & $\boldsymbol{\alpha}$ & Sig $>\boldsymbol{\alpha}$ \\
\hline 1 & Eksperimen 1 & 19 & & & \\
2 & Eksperimen 2 & 21 & 0,952 & 0,05 & Homogen \\
3 & Kontrol & 23 & & & \\
\hline
\end{tabular}

Berdasarkan Tabel 8 diketahui masing-masing kelas populasi memiliki nilai signifikansi lebih dari $\alpha(0,05)$, sehingga dapat disimpulkan bahwa semua kelas populasi memiliki data varian yang sama atau homogen.

Tabel 9. Hasil Uji Homogenitas Kemampuan Berpikir Kreatif

\begin{tabular}{llcccc}
\hline No & \multicolumn{1}{c}{ Kelas } & N & Sig & $\boldsymbol{\alpha}$ & Sig $>\boldsymbol{\alpha}$ \\
\hline 1 & Eksperimen 1 & 19 & & & \\
2 & Eksperimen 2 & 21 & 0,667 & 0,05 & Homogen \\
3 & Kontrol & 23 & & & \\
\hline
\end{tabular}

Berdasarkan Tabel 9 diketahui memiliki hubungan linier terhadap masing-masing kelas populasi memiliki nilai signifikansi lebih dari $\alpha(0,05)$, sehingga dapat disimpulkan bahwa semua kelas populasi memiliki data varian yang sama atau homogen.

Setelah dilakukan ui normalitas dan uji homogenitas, selanjutnya dilakukan uji linieritas, yang bertujuan untuk melihat apakah kemampuan awal matematika sebagai variabel kovariat kemampuan berpikir kreatif sebagai variabel terikat. Untuk uji linieritas data yang digunakan dalam penelitian ini yaitu menggunakan uji linierity dengan bantuan IBM SPSS Statistik 21.

Berikut hasil pengujian linieritas homogenitas pada kemampuan awal matematika (kovariat) dengan kemampuan berpikir kreatif pada Tabel 10.

Tabel 10. Hasil Uji Linieritas

ANOVA Table

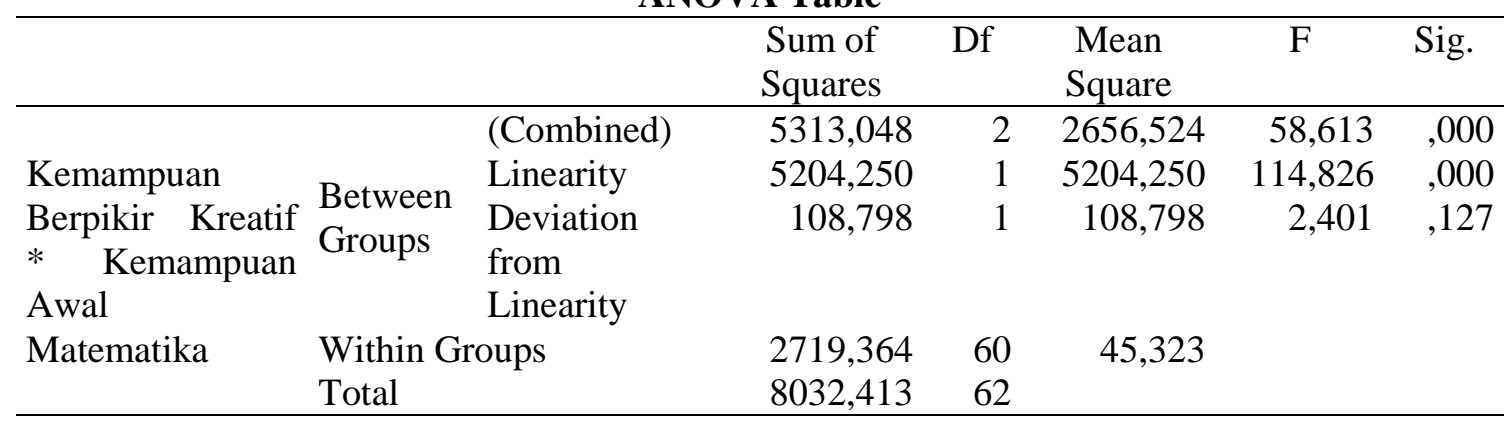


Diketahui nilai signifikansi Deviation from Linearity pada Tabel 10 adalah sebesar 0,127 dengan nilai $\alpha$ sebesar 0,05 pada tarap pengambilan keputusan jika sig $>\alpha$ maka diterima. Maka 0,127 > 0,05 dapat disimpulkan bahwa terdapat hubungan linier antara kemampuan berpikir kreatif dengan kemampuan awal matematika sehingga asumsi ancova telah terpenuhi.

Setelah uji persyaratan analisis dilakukan, maka langkah selanjutnta

Tabel 11. Hasil Hipotesis

Tests of Between-Subjects Effects

Independen Variable: K.Berpikir.Kreatif

\begin{tabular}{lrrrrr}
\hline \multicolumn{1}{c}{ Source } & $\begin{array}{c}\text { Type III Sum } \\
\text { of Squares }\end{array}$ & Df & $\begin{array}{c}\text { Mean } \\
\text { Square }\end{array}$ & F & Sig. \\
\hline Corrected Model & $5738,296^{\mathrm{a}}$ & 3 & 1912,765 & 49,192 &, 000 \\
Intercept & 5905,476 & 1 & 5905,476 & 151,877 &, 000 \\
K.Awal & 4673,696 & 1 & 4673,696 & 120,198 &, 000 \\
Model & 676,269 & 2 & 338,134 & 8,696 &, 000 \\
Error & 2294,116 & 59 & 38,883 & & \\
Total & 283782,000 & 63 & & & \\
Corrected Total & 8032,413 & 62 & & \\
\hline \multicolumn{5}{c}{ a. Squared $=, 714$ (Adjusted R Squared $=, 700)$} \\
\end{tabular}

$$
\text { a. } R \text { Squared }=, 714 \text { (Adjusted } R \text { Squared }=, 700 \text { ) }
$$

Berdasarkan Tabel 11 hasil uji hipotesis, didapat hasil keputusan sebagai beriku:

Hipotesis 1

Hipotesis pertama yang diajukan dalam penelitian ini adalah apakah terdapat pengaruh model pembelajaran NHT integrated terhadap kemampuan berpikir kreatif dengan mengontrol kemampuan awal matematika siswa. Pada kriteria pengujian jika signifikansi $<\alpha(0,05)$ maka hipotesis diterima. Berdasarkan data pada Tabel 11 diketahui Model dengan nilai $\mathrm{F}_{\text {hitung }}=$ $8,696>\mathrm{F}_{\text {tabel }} 3,15$ dan taraf signifikansi 0,000 jika dibandingkan dengan nilai $\alpha$ $(0,05)$ maka $0,000<0,05$ dan hipotesis di terima.

Dengan demikian dapat dinyatakan bahwa terdapat pengaruh model pembelajaran NHT integrated terhadap kemampuan berpikir kreatif dengan mengontrol kemampuan awal matematika siswa.

Hipotesis 2

Hipotesis kedua yang di ajukan dalam penelitian ini adalah apakah terdapat perbedaan model pembelajaran NHT integrated terhadap kemampuan berpikir kreatif dengan mengontrol kemampuan awal matematika siswa. Pada kriteria pengujian jika signifikansi $<\alpha(0,05)$ maka hipotesis diterima. Berdasarkan data pada Tabel 11 diketahui Corrected Model dengan nilai $\mathrm{F}_{\text {hitung }}=49,192>\mathrm{F}_{\text {tabel }}$ 3,15 dan taraf signifikansi 0,000 jika dibandingkan dengan nilai $\alpha(0,05)$ maka $0,000<0,05$ dan hipotesis di terima. Dengan demikian dapat dinyatakan bahwa terdapat perbedaan model pembelajaran NHT integrated terhadap kemampuan berpikir kreatif dengan mengontrol kemampuan awal matematika siswa.

\section{8 | AKSIOMA}

Jurnal Pendidikan Matematika FKIP Univ. Muhammadiyah Metro 
Dikarenakan memiliki perbedaan pada model pembelajaran yang diterapkan terhadap kemampuan berpikir kreatif, maka dilakukan uji lanjut untuk mengetahui rataan manakah yang berbeda pada masingmasing kelompok model yang diterapkan pada tiap-tiap kelas eksperimen 1, eksperimen 2 dan control pada Tabel

12.

\section{Tabel 12. Uji Lanjut}

Pairwise Comparisons

Dependent Variable: K.Berpikir.Kreatif

\begin{tabular}{|c|c|c|c|c|c|c|}
\hline \multirow[t]{2}{*}{ (I) Model } & \multirow[t]{2}{*}{ (J) Model } & \multirow{2}{*}{$\begin{array}{c}\text { Mean } \\
\text { Difference } \\
(\mathrm{I}-\mathrm{J})\end{array}$} & \multirow[t]{2}{*}{$\begin{array}{l}\text { Std. } \\
\text { Error }\end{array}$} & \multirow[t]{2}{*}{ Sig. ${ }^{b}$} & \multicolumn{2}{|c|}{$\begin{array}{c}95 \% \text { Confidence } \\
\text { Interval for Difference }\end{array}$} \\
\hline & & & & & $\begin{array}{l}\text { Lower } \\
\text { Bound }\end{array}$ & $\begin{array}{l}\text { Upper } \\
\text { Bound }\end{array}$ \\
\hline NHT integrated & NHT integrated & ,231 & 1,977 & ,907 & $-3,724$ & 4,187 \\
\hline Kelas Eksperimen & $\begin{array}{l}\text { Kelas Eksperimen } 2 \\
\text { NHT Biasa } \\
\text { Kelas Kontrol }\end{array}$ & $6,953^{*}$ & 1,944 & ,001 & 3,064 & 10,842 \\
\hline NHT integrated & NHT integrated &,- 231 & 1,977 & ,907 & $-4,187$ & 3,724 \\
\hline Kelas Eksperimen & $\begin{array}{l}\text { Kelas Eksperimen.1 } \\
\text { NHT Biasa } \\
\text { Kelas.Kontrol }\end{array}$ & $6,722^{*}$ & 1,885 & ,001 & 2,950 & 10,493 \\
\hline & NHT integrated & $-6,953^{*}$ & 1,944 & ,001 & $-10,842$ & $-3,064$ \\
\hline NHT Biasa & Kelas Eksperimen.1 & & & & & \\
\hline Kelas Kontrol & $\begin{array}{l}\text { NHT integrated } \\
\text { Kelas Eksperimen.2 }\end{array}$ & $-6,722^{*}$ & 1,885 &, 001 & $-10,493$ & $-2,950$ \\
\hline
\end{tabular}

Based on estimated marginal means

*. The mean difference is significant at the, 05 level.

b. Adjustment for multiple comparisons: Least Significant Difference (equivalent to no adjustments).

Berdasarkan data pada Tabel 12 tentang uji lanjut model pembelajaran NHT integrated pada kelas eksperimen 1 memiliki perbedaan hasil belajar kemampuan berpikir terhadap model pembelajaran NHT konvensional pada kelas kontrol, yang dibuktikan dengan taraf signifikasni $0,001<0,05$ yang berarti bahwa model pembelajaran pada kelas ekperimen 1 lebih baik dari model pembelajaran pada kelas kontrol.

Pada model NHT integrated pada kelas eksperimen 2 memiliki perbedaan hasil belajar kemampuan berpikir kreatif terhadap model pembelajaran NHT konvensional pada kelas kontrol, yang dibuktikan dengan taraf signifikasni $0,001<0,05$ yang berarti bahwa model pembelajaran pada kelas ekperimen 2 lebih baik dari pada model pembelajaran pada kelas kontrol.
Namun model pembelajaran NHT integrated pada kelas eksperimen 1 dan kelas eksperimen 2 tidak memiliki perbedaan hasil belajar kemampuan berpikir kreatif, yang dibuktikan dengan taraf signifikasni $0,907>0,05$ yang berarti bahwa model pembelajaran NHT integrated yang diterpakan pada kedua kelas eksperimen sama-sama dapat meningkatkan kemampuan berpikir kreatif siswa meskipun telah dicobakan kepada dua kelas yang berbeda, sehingganya hal ini berdampak pada prestasi belajar siswa.

Pada proses pembelajaran menggunakan model pembelajaran NHT integrated siswa dibekali proses pembelajaran yang bertujuan untuk melatih kemampuan berpikir kreatif bagi siswa dengan aktifitas belajar seperti meminta siswa untuk menelaah atau membahas materi yang tercangkup 
dalam suatu pelajaran (berupa LKS), siswa melakukan komponen-komponen pembelajaran secara ilmiah terkait mengamati suatu objek atau masalah pada LKS, kemudian melatih keberanian siswa dalam mengajukan pendapat dan pertanyaan, melatih kerjasama siswa dalam mengumpulkan informasi secara berkelompok, melatih cara berpikir siswa dalam bernalar, dapat mengkomunikan informasi serta mengajak siswa menjadi lebih aktif dalam belajar.

Menurut Musfiqon \& Nurdyansyah (2015:45) mengatakan bahwa langkah ilmiah yang diterapkan untuk memberikan ruang lebih pada peserta didik dalam membangun kemandirian belajar serta mengoptimalkan potensi kecerdasan yang dimiliki. Peserta didik diminta untuk mengkonstruk sendiri pengetahuan, pemahaman, serta skill dari proses belajar yang dilakukan, sedangkan tenaga pendidik mengarahkan serta memberikan penguatan dan pengayaan tentang apa yang dipelajari bersama peserta didik.

Dalam model pembelajaran NHT integrated siswa juga di cek pemahamannya terkait materi yang dipelajari. Pengecekan pemahaman siswa dilakukan dengan kuis, kemudian diberikan penghargaan bagi siswa dan kelompok berupa pemberian barang alat tulis/perlengkapan belajar yang berdsarkan pada skor perkembangan yang dimiliki siswa. Model pembelajaran NHT integrated juga dapat membantu siswa dalam berpikir, karena selama proses pembelajaran menuntut siswa untuk saling bekerjasama, sehingga siswa dengan kemampuan awal tinggi dapat membimbing siswa dengan kemampuan awal sedang dan rendah. Hal ini membuat siswa dengan kemampuan awal sedang dan rendah mulai terbiasa dalam mengungkapkan pendapat mereka dan dapat memberikan semangat dalam belajar serta melatih keterampilan kerjasamanya.

Huda (2012: 138) menyatakan bahwa ketika siswa menyatukan kepala untuk berpikir, siswa akan terlatih mengemukakan pendapat, berlatih menghargai pendapat orang lain, belajar menerima ketika pendapatnya belum diterima dan siswa dapat berlatih menjadi tutor sebaya kepada anggota yang belum paham. Hal ini juga sejalan dengan penelitian yang dilakukan Santi, Suarman \& Indrawati (2017) dalam penelitiannya yang berjudul kombinasi NHT-STAD untuk meningkatkan kemampuan berpikir kreatif dan kritis siswa yang menyatakan bahwa terdapat penggunaan model kombinasi NHTSTAD menghasilkan kemampuan berpikir kreatif yang berbeda antara siswa kelas rata-rata tertinggi dan kelas rata-rata terendah, dimana siswa kelas rata-rata tertinggi memiliki kemampuan berpikir kreatif siswa yang lebih baik dari pada rata-rata kelas rata-rata terendah. Kemudian penelitian yang dilakukan oleh Wardani (2015) berjudul pengaruh pembelajaran kooperatif tipe Numbered Heads Together (NHT) terhadap kemampuan berpikir kreatif dan hasil belajar matematika kelas VII MTS yang menyimpulkan bahwa terdapat pengaruh penerapan model pembelajaran NHT terhadap kemampuan berpikir kreatif.

Dengan
disimpulkan $\begin{gathered}\text { demikian } \\ \text { bahwa }\end{gathered}$ dapat
meningkatkan
kemampuan berpikir
keatif dalam penelitian ini tidak hanya
kemampuan awal yang mempengaruhi,
namun juga terdapat pengaruh model
pembelajaran NHT integrated.

\section{KESIMPULAN DAN SARAN}

Berdasarkan analisis yang telah di lakukan, didapat kesimpulan yaitu: (1) 
Terdapat pengaruh model pembelajaran NHT integrated terhadap kemampuan berpikir kreatif dengan mengontrol kemampuan awal matematika, di dapat signifikansi $0,000<0,05$ dengan $\mathrm{F}_{\text {hitung }}$ $=8,696>\mathrm{F}_{\text {tabel }} 3,15$ sehingga didapat kesimpulan bahwa terdapat pengaruh model pembelajaran NHT integrated terhadap kemampuan berpikir kreatif dengan mengontrol kemampuan awal matematika. (2) Terdapat perbedaan model pembelajaran NHT integrated terhadap kemampuan berpikir kreatif dengan mengontrol kemampuan awal matematika. Pada signifikansi $0,000<$ 0,05 dengan $F_{\text {hitung }}=49,192>F_{\text {tabel }} 3,15$ sehingga didapat kesimpulan bahwa terdapat perbedaan model pembelajaran NHT integrated terhadap kemampuan berpikir kreatif dengan mengontrol kemampuan awal matematika.

Berdasarkan hasil penelitian yang diperoleh, terdapat beberapa saran yaitu: (1) Sebagai bahan pertimbangan untuk penelitian yang relevan berkaitan dengan model pembelajaran NHT integrated dalam meningkatkan kemampuan berpikir kreatif dengan mengontrol kemampuan awal siswa. (2) Guru diharapkan mampu mengoptimalkan kemampuannya sebagai fasilitator dalam proses pembelajaran berdasarkn model yang diterapkan, agar tidak ada lagi pembelajaran yang berpusat kepada guru meskipun telah menerapkan model pembelajaran. (3) Dalam penerapan model pembelajaran NHT Integrated guru diharapkan benar-benar memperhatikan kegiatan siswa dalam langkah kerja ilmiah, agar siswa dapat mengembangkan kemampuannya disetiap langkah kegiatan pembelajaran.

\section{DAFTAR PUSTAKA}

Ali, M. \& Asrori, M. (2009). Psikologi Remaja Perkembangan Peserta Didik. Jakarta: Bumi Aksara.

Anwar, N. M. R. \& Haq. (2012). A Comparison of Creative Thinking Abilities of High and Low Achievers Secondary School Students. International Interdiciplinary Journal of Education, Vol. 1, Issue 1, 1-6.

Creswell, J. W. (2008). Educational Research Planning, Conducting And Evaluating Quantitative And Qualitative Research (Eds Thrid). Peson Education, Inc. Upper Saddle River, New Jersey.

Faturrahman, Ahmadi, Amri \& Setyono. (2012). Pengantar Pendidikan. Jakarta: Prestasi Pustaka Publisher.

Hendriana \& Soemarmo. (2017). Penilaian Pembelajaran Matematika (Eds). Bandung. PT. Refika Aditama.

Huda, M. (2012). Cooperatif Learning Metode Teknik, Struktur Dan Model Penerapan. Jakarta. Pustaka Pelajar.

Musfiqon \& Nurdyansyah. (2015). Pendekatan Pembelajaran Saintifik. Sidoarjo: Nizamia Learning Center.

Prayoga, A. (2011). Srategi Pembelajaran Aktif, Inovatif, Efektif Dan Menyenangkan. Jakarta: Pustaka Media.

Rudyanto, E. H. (2016). Model Discovery Learning Dengan Pendekatan Saintifik Bermuatan 
ISSN 2089-8703 (Print) Vol. 7, No. 3 (2018) 390-402

ISSN 2442-5419 (Online)

Karakter Untuk Meningkatkan Kemampuan Berpikir Kreatif. Premiere Educandum, Volume 4 Nomor 1, Juni 2014, 41-48.

Santi, S. \& Indrawati. (2017). Kombinasi NHT-STAD pada mata pelajaran ekonomi untuk meningkatkan kemampuan berpikir kreatif dan kritis siswa (studi kasus pada siswa kelas $\mathrm{X}$ SMAN 1 Kubu Babussalam). Pekbis Jurnal, Vol.8 No.3 (164171).

Sulistyana. (2017). Pengaruh Model Pembelajaran Kooperatif Tipe Numbered Heads Together Terhadap Berpikir Kreatif Siswa Kelas X SMA Azhakyah. SKRIPSI: Palembang.
Supardi, U. S. (2012). Peran Berpikir Kreatif Dalam Proses Pembelajaran Matematika. Jurnal Formatif 2(3): 248-262. ISSN: 2088-351X.

Supardi, U. S. 2014. Aplikasi Statistika Dalam Penelitian. Yogyakarta: STAIN Purwokerto Press.

Wardani, R. N. I. 2015. Pengaruh Pembelajaran Kooperatif Tipe Numbered Heads Together (NHT) Terhadap Kemampuan Berpikir Kreatif dan Hasil BelAJar Matematika Kelas VII di MTs Sultan Agung Jabalsari. SKRIPSI: Tulungagung. 